\title{
Effective Classroom Management: A Sine Qua Non to Effective Teaching in a School Setting
}

Ige Akindele Matthew: Ondo State Ministry of Education, Science, and Technology, Akure, Ondo State, Nigeria.

\begin{abstract}
A classroom is a place where a teacher teaches the learners and where the learners learn from a teacher. Being the workshop of a teacher where teaching and learning take place, the management of a classroom needs to be accorded priority attention. It is believed that if classroom management is given attention, so will effective teaching be achieved. In this paper, the issue of effective classroom management is examined, with a focus on the elements, such as the effective use of chalkboard, communication, use of teaching aids/instructional materials, evaluation of lesson, and management of behavioural challenges, such as noise-making, sleeping, fighting, reading, writing, eating, hissing, foot-dragging, just to mention a few; as well as the management of classroom environment, are examined. The paper recommends how to achieve effective classroom management and ultimately, effective teaching in a classroom setting, such as effective use of chalkboard, communication, use of instructional materials, evaluation of lesson, and management of behavioural challenges.
\end{abstract}

Keywords: Effective, Classroom, Management, Classroom management, A sine qua non, Teaching, School, Setting. JEL Classification: 129.

\section{Introduction}

Teaching has been described as a process of transmitting knowledge from an individual to another and a complex process in which a learner is made to pay attention, observe, associate ideas, remember previous experiences, as well as reason. It is also an active systematic process guiding the learners to acquire necessary information, knowledge, and skills that would lead to the desired positive behavioural change (Rakum, 2007).

Teaching can be effective or non-effective. According to Duyilemi (1998), cited in Nwagbo (2008), teaching is effective when the method of its delivery enables the learners to link their learning experiences to the home/community experiences, solve individual's and society's problems. It is important to note that effective teaching requires considerable skill in the management of the tasks and situations in a classroom. When teaching is effective, there is high hope that the objectives of a lesson will be achieved while it will improve the learner's understanding of the lesson, which is capable of ensuring good performance of the learner in tests and examinations.

\subsection{What is a Classroom?}

Every profession has a place where members practice and attend to customers/clients. A banker works in a bank, a lawyer handles cases in the courtroom while an engineer works in the workshop. A classroom is the

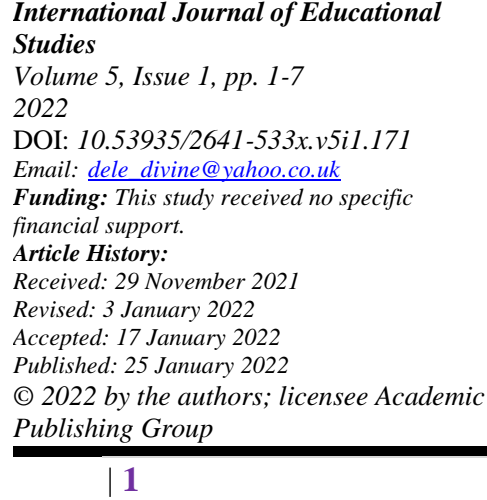


workshop of a teacher where he/she demonstrates his/her teaching skill and passes knowledge across to the learners. According to Wikipedia, a classroom is a space, a room, in which children and adults learn.

Classrooms are of varying sizes. At the lower levels of the educational system (i.e. the primary and secondary), classrooms are of average size because of the limited number of learners that should be inside it at a time. Due to the high population in tertiary institutions, a large classroom is needed to accommodate the learners at a time. There are however very large classrooms, such as lecture theatre or auditorium, which can contain a larger population of learners at a time. In a secondary school setting, computer, science, and language laboratories are special classrooms where teaching and learning take place, on particular subjects, for example, the Chemistry laboratory is meant for the teaching of Chemistry while the Biology laboratory is for the teaching of Biology. A classroom is characterised by: a large writing surface where a teacher can write the important points in a lesson and notes for the learners, to make the teaching understandable to the learners. This can either be a chalkboard, made of cement block and attached to the wall in front of the classroom, or in form of a flipchart, whiteboard, and interactive whiteboard. Also, there are chairs and lockers/desks for the use of learners, usually arranged in rows, with space in between the rows, to give room for easy passage by the teacher and learners. While a chair is meant for a learner to sit, to receive a lesson, a learner needs a locker to write notes in the classroom. In the tertiary institutions, only chairs are present but with an extension for the learners to write notes during lesson delivery. Aside from these, a classroom possesses the teacher's chair and table, for a teacher to sit and write, as well as the walls, windows, to give room for illumination and allow natural air to penetrate. In some cases, classrooms may have Television, Maps, Charts, Monographs, and Projectors for presenting information and images from a computer for better understanding by the learners.

\subsection{Classroom Management Concept and Importance}

According to Nwachukwu (1988), management is the process of getting things done through others, and the coordination of the resources of an organisation, through the process of planning, organising, directing, and controlling, to achieve the organisation's objectives. Dunham \& Pierce (1989), cited in Borism and Jens (2019) also see it as the process of planning, organizing, directing, and controlling organizational resources (human, financial, physical, and informational) in the pursuit of organizational goals. Planning means to plan, while organising is the coordination of human and material resources. Actuating is the motivation and giving of direction to the subordinates while controlling is meant to ensure the implementation of a plan without deviation. From whatever perspective it is viewed, management can be described further as a process that demands the performance of specific functions, such as the coordination of human, materials, and financial resources, to achieve an organisation's objectives.

The universality of management is an important and popular principle in management, which connotes that managerial skills are transferable from an organisation to another. Whether in the military, business organisation, government establishment, or others, managerial activities are the same, in other words, managers perform the same functions, irrespective of the type of organisation each belongs to. As applicable in other organisations, management takes place in a classroom, the teacher being the manager, who coordinates other resources, including the learners, facilities, teaching aids, and infrastructure, to achieve the lesson's objectives. All the activities in a classroom are thus within his/her control. Classroom management is the wide variety of skills and techniques that teachers use to keep learners organised, orderly, focused, attentive on task, and academically productive in a classroom. It is also a process by which teachers and schools create and maintain appropriate behaviour in classroom settings; as well as encompasses everything which a teacher can do to make sure that his/her lesson is delivered to the best capacity, without any disruption from any quarter and with the learners gaining maximally at the end of it. It thus entails tackling or controlling the disruptive behaviours that can impede the achievement of the lesson's objectives and promoting or encouraging those behaviours that can guarantee the achievement of such objectives in the classroom. When a teacher fails to manage a class effectively, learning will be impeded while the achievement of the lesson's objectives will be a mirage.

The importance of classroom management cannot be underemphasised. According to Evertson and Weinstein (2006), it helps to enhance pro-social behaviour and increase learners' academic engagement. Classroom management also brings about harmony and orderliness in the classroom, as well as prevents the misbehaviour of learners (National Teachers Institute, 2013). Oliver, Wehby, and Reschly (2011) observed that teachers who use effective classroom management will experience improvement in learners' behaviour,

\author{
Internation
Studies \\ Volume 5, Issue 1, pp. 1-7 \\ 2022 \\ DOI: $10.53935 / 2641-533 x . v 5 i 1.171$ \\ Email:dele_divine@yahoo.co.uk \\ Funding: This study received no specific \\ financial support. \\ Article History:
Received: 29 November 2021 \\ Revised: 3 January 2022 \\ Accepted: 17 January 2022 \\ Published: 25 January 2022 \\ (C) 2022 by the authors; licensee Academic \\ Publishing Group
}


and the improvement that establishes the context for effective instructional practices will occur. Aanuoluwapo and Akinyemi (2016) also opined that good classroom management has a positive effect on decreasing problem behaviour in the classroom, while Rockoff (2004) emphasised that teaching quality include creating a positive learning climate, selecting appropriate instructional goals and assessments, using the curricula effectively, as well as employing varying instructional behaviours that help all learners to learn at higher levels.

\subsection{How to Achieve Effective Classroom Management}

In a classroom, a teacher can be likened to a shepherd who controls a flock of sheep. He/she has to do everything possible within the limit of his/her power to ensure that there is orderliness in the classroom while teaching the learners to achieve the lessons' objectives. When a teacher is in a classroom, he/she has to prove the competency to deal with the situations that may arise at any time. Failure to do so will amount to the incompetency of such a teacher. In the recent past, the author noticed in a classroom while teaching was in progress, that most of the learners were playing, while some were making noise, and some sleeping. In that situation, the teacher cannot achieve the desired objectives and the consequence will be mostly felt by the learners who in the end, may fail to understand the rudiments of the lesson and could ultimately result in failure in examination(s). Achieving effective classroom management is not an easy task for a teacher because of the forces that may manifest while teaching. A teacher must however be at an alert, to ensure that everything is put in place while planning to teach and during teaching. Achieving effective classroom management entails that a teacher has to ensure that all the aspects of teaching are carried out without any hitch. There are issues in a classroom that a teacher must manage so that the objectives of his/her lesson can be achieved. A teacher needs to perform diverse roles, to ensure effective classroom management and learning outcomes. According to Carmen (2019), the role of a teacher should include the management of the classroom in a manner that meets the individual needs of each student in the class, which should include: promoting learning and supplementing activities, coordinating and collaborating with support staff, using a variety of teaching approaches, as well as adapting instruction to include all students. A teacher who fails to achieve the lesson's objectives can be likened to a driver who drives his/her passengers to a bush, rather than to the desired destinations and thus requires extra effort to drive them back.

For a teacher to be able to manage a classroom effectively, he/she must be able to design well-established principles, rules, and regulations. The benefits of having these are many but according to the National Teachers Institute (2013), these can help the learners understand what is (are) expected of them, makes it easier for them to be organised into doing different activities in the classroom, make the learners imbibe the habit of treating each other well, as well as help to manage a classroom better.

Effective classroom management involves some fundamentals, such as:

- Knowing what a teacher wants and what he/she doesn't want.

- Showing and telling learners what a teacher wants.

- When a teacher gets what he/she wants, acknowledging it.

There are activities that a teacher must carry out dutifully in a classroom, for effective management to be achieved. It is thus not an easy task for a teacher to achieve effective teaching in a classroom. All these activities work together to give room for effective teaching, in other words, where a teacher fails to perform any of these activities very well in a classroom, achievement of effective teaching may end up being a mirage.

\subsection{Use of Chalkboard}

A chalkboard is very essential for teaching because this is where a teacher has to write the topic of the lesson, the date, as well as the main points of a lesson, for the learners to see. In a classroom, a chalkboard must be visible from all points, properly managed by a teacher, to achieve its purpose. There should be orderliness in the way it is used by a teacher. A teacher should not use the chalkboard haphazardly. He/she needs to divide it into parts, depending on the size, and use a part completely before the other. A teacher has to write boldly, legibly, and orderly on the chalkboard. Where the writings are not bold enough, legible, and orderly, the learners may find it difficult to see these. He/she should avoid writing on it indiscriminately, i.e. without a pattern, such that will not portray him/her as a professional teacher. Where a teacher is using a particle or movable board with a marker, he/she should ensure that there is ink in the marker and write clearly

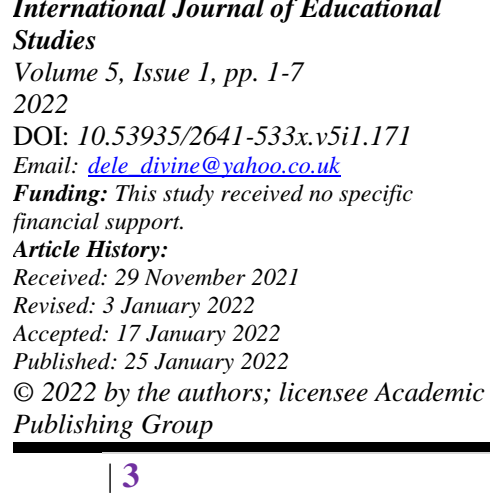
on the board for the learners to see. The chalkboard must be cleaned before the arrival of the teacher. This can 
be achieved through the effort of the Class Captain who has to use his/her leadership power to call any of the learners out to do this. In the course of teaching, he/she can do the same. Allowing a teacher to clean the board himself/herself will waste some of the allocated time for a lesson.

\subsection{Management of Time}

Time is very precious and should be treated as such by a teacher. A lesson has a specific duration while a teacher should ensure that he/she keep to the allocated time and plan his/her lesson before the actual teaching. Each aspect of a lesson needs to be allocated a specific time frame, while the teacher should ensure that he/she keep to the allocated time. When a teacher spends more than the allocated time for a lesson, this can disturb other teachers from teaching at the appropriate time. A teacher should thus avoid distractions that can make him/her deviate from the lesson. He/she should also set aside part of the time for the evaluation process, to confirm that the learners understand the rudiments of the lesson. While using instructional materials/teaching aids, a teacher should not overspend time on this, ditto when the teacher is addressing the issue of indiscipline among the students in the classroom.

\subsection{Management of Communication Process}

If learners will understand the content of a lesson or not, depends on the nature of the communication adopted by a teacher. A teacher should communicate the content of his/her lesson in a manner that will be clear to the learners. The voice of a teacher should be audible enough for the learners. If it is low or soft, learners may find it difficult to understand the content of the lesson which can lead to noise-making from the learners. If the voice of a teacher is too loud, it may affect the concentration of the learners and complicate the situation for those learners having hearing problems. A teacher should therefore communicate using the simple, clear, and correct language. Where a teacher uses heavy grammar, this may discourage the learners from coming to the classroom to attend his/her lessons while the use of high-level vocabularies during teaching may not give room for proper understanding of the content of a lesson by the learners. A teacher should thus communicate the content of his/her lesson using the appropriate medium of instruction. An improper communication strategy can make the learners pay less attention to a lesson and thus result in noise making.

\subsection{Management of Classroom Environment}

A classroom environment consists of walls, doors or doors, windows, desks and benches or chairs, chalkboards, as well as teacher's tables. A teacher is expected to manage the classroom environment, taking into cognisance, the components. He/she needs to organise the environment and materials so that they assist in achieving the desired teaching objectives. Before the commencement of teaching, a teacher needs to ensure that the classroom is kept tidy because a dirty environment can make the learners uncomfortable during teaching. Out (2002) identified the features of learners' friendly classroom as cleanliness, tidiness, among others. Where papers are found littering the floor of a classroom, the teacher should ensure that they are picked by the learners, quietly and quickly, and thrown into a Dustbin/Wastebasket. A classroom should be properly swept with chairs and lockers well arranged. Space must also be allowed between the rows, to give room for easy movement of the teacher, learners, or visitor(s) to the classroom. According to Marland (1975), careful attention to seating arrangements, contributes more than any other aspect of classroom management, to the control of the classroom. Adequate space must also be left for important matters, such as storage corners for reading tables. Learners must be able to move about without disturbing each other in the process, while furniture must be easy to move around for other activities in the classroom, such as group work, demonstration of the lesson, storytelling, among others (National Teachers Institute, 2013). The teacher's table needs to be placed at the front of a classroom where the learners can see him/her vividly. Teaching aids/instructional materials to be used for teaching, such as chalk, duster, ruler, among others should be ready. A teacher should avoid the habit of leaving the classroom to collect any of such materials while teaching, which is capable of distracting the learners' attention and wasting part of the time allotted for teaching. Such materials to be used for teaching should be arranged on top of a table in the classroom. A teacher has to observe the sitting arrangement of learners and if found to be inappropriate, correct this. Learners who are tall should occupy the back seats while shorter learners should be at the front seats so that the taller learners would not obscure the view of the shorter ones in the classroom. Learners having eye defect (s) should be

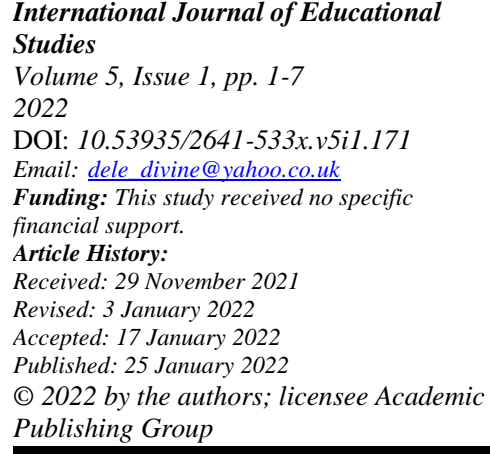


strategically positioned in the classroom, depending on the nature of such defect. Re-arrangement of learners should take less time so as not to waste part of the lesson duration. In the course of teaching, a teacher should demonstrate that he/she has proper control of the classroom situation.

\subsection{Management of Evaluation Process}

A teacher needs to ascertain the extent to which the objectives of a lesson have been achieved so that adjustments can be made to improve the situation when it is necessary. In a classroom, evaluation can be achieved through questioning or the conduct of tests for the learners. A lesson can be evaluated during delivery or at the end, depending on the decision of the teacher. Where a teacher prefers oral questioning, the teacher has to raise questions for the learners to answer. While raising such questions, the teacher should not give room for chorus answering of the questions which can make the whole classroom rowdy. Such a teacher has to call the learners one after the other, to answer the question. If a learner is unable to answer a question correctly, other learners whose hands are raised should be allowed to try, until the question is answered correctly. A teacher can also write questions on the chalkboard and allow a learner to write the answer on the chalkboard for others to see. This will also encourage teacher-learners interaction.

\subsection{Use of Instructional Materials/Teaching Aids}

Instructional materials/teaching aids are important during teaching because they complement the level of explanations given by a teacher. According to Aanuoluwapo and Akinyemi (2016), the use of instructional materials, such as charts, pictures, diagrams, or real objects, is important and necessary to aid teaching and students' learning. When such materials are not used appropriately, it can affect classroom management, i.e. disorganise a class. There are approaches that a teacher can adopt while planning to use instructional materials(s) in a classroom. The first is to show the material to the learners while in their seats. Although this is time-consuming, it will enable the learners to catch a proper glimpse of the material. Another approach is to place the material on a table at the front of the class and ask the learners to move out in rows i.e. one row after the other, to view such material. The third approach is to divide the learners into groups and show the material to each group before another. Some instructional materials, such as pictures or cardboard can be hanged, or fasten onto the chalk/movable board, while the learners can be asked to step out to look at it one after the other. In some cases, a teacher can use illustrations to support his/her teaching. He/she can call some of the learners out and use them for illustration.

\subsection{Management of Behavioural Challenges}

Aside from the major tasks earlier discussed, which can contribute to the achievement of effective classroom management, a teacher should be able to manage effectively, the abnormal behaviours noticed among the learners during the actual teaching. This is indeed the crux of the matter. When a teacher is in a classroom, learners are bound to display abnormal behaviours, which if not checked, can mar the teaching process and make a teacher say goodbye to effective classroom management and the achievement of the lesson's objectives. A teacher should thus be vigilant while teaching and should not feel unconcerned when any of the behaviours manifest during teaching. A teacher must however be consistent, considerate, confident, and show candor while managing behaviour challenges in the classroom. Being consistent implies that such a teacher has to be reliable and must not change behaviour while dealing with cases. He/she must show the same treatment to the same behaviour challenge when it comes. Being considerate is to respect the learners and be aware of their likes and dislikes. He/she must take time to establish rapport with them. Confidence is a trait needed to make a decision(s) that reflect careful thought, free of bias and based on evidence. A teacher should know when to stand up for his/her opinions and decisions, as well as how to compromise or agree with others, based on evidence. Candor implies that a teacher is open and honest in the actions taken with learners, fellow teachers, and himself/herself. It means being frank, fair and candour is the ability to admit a mistake made and unafraid or unashamed to apologise.

For behaviour challenges to be properly managed in a classroom, the teacher should:

- Ensure quick intervention, i.e. respond promptly.

- Use appropriate/develop reinforcement schedules and use these with misbehaved learners.

- Instruct learners with a behaviour problem in a self-controlled skill.

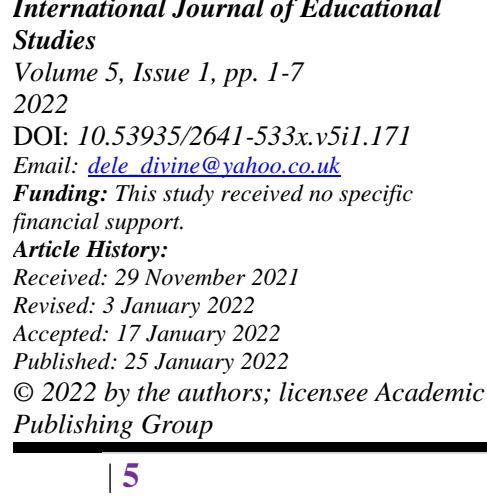


- Teach the misbehaved learners, how to observe their behaviour task to themselves through appropriate behaviour patterns.

- Teach the misbehaving learners general pro-social skills, self-awareness, cooperation, and helping.

- Place misbehaving learners in peer tutoring arrangements, having them serve as tutors or tutees.

- Make use of punishment which are reasonable for the offense committed and provide support to help learners improve their behaviour.

\begin{tabular}{|c|c|c|}
\hline $\mathbf{S} / \mathbf{N}$ & $\begin{array}{l}\text { Behavior } \\
\text { challenge }\end{array}$ & How to deal with it \\
\hline 1 & $\begin{array}{l}\text { Sleeping by the } \\
\text { learner(s) }\end{array}$ & $\begin{array}{l}\text { Such learner(s) can be commanded to be on his/her/their feet for a few minutes or given a } \\
\text { strenuous exercise such as running around the field to energise the muscles before returning } \\
\text { to the classroom. } \\
\text { If it is due to teaching style, a teacher should make his/her teaching to be interactive between } \\
\text { him/her and the learner(s). }\end{array}$ \\
\hline 2 & $\begin{array}{l}\text { Eating by the } \\
\text { learner(s) }\end{array}$ & $\begin{array}{l}\text { The teacher should collect the food and keep it for the learner(s) till the end of the lesson. } \\
\text { Such learner(s) can also be punished, to serve as a deterrent to others }\end{array}$ \\
\hline 3 & $\begin{array}{l}\text { Fighting by } \\
\text { learners }\end{array}$ & $\begin{array}{l}\text { The teacher should remove such learners from their positions and place them at the front of } \\
\text { the class. They can be punished in the presence of other learners. }\end{array}$ \\
\hline 4 & $\begin{array}{l}\text { Talking by } \\
\text { learners. }\end{array}$ & $\begin{array}{l}\text { The teacher should separate the learners involved and assign appropriate punishment to } \\
\text { them. }\end{array}$ \\
\hline 5 & $\begin{array}{l}\text { Reading by } \\
\text { learner }\end{array}$ & $\begin{array}{l}\text { The teacher should collect the notebook or textbook from such learner, punish him/her to } \\
\text { serve as a deterrent to others. }\end{array}$ \\
\hline 6 & $\begin{array}{l}\text { Restlessness by } \\
\text { learner }\end{array}$ & $\begin{array}{l}\text { The concerned learner should be removed from his/her seat and placed on a seat very close } \\
\text { to the teacher for proper monitoring. }\end{array}$ \\
\hline 7 & $\begin{array}{l}\text { Looking } \\
\text { outside }\end{array}$ & $\begin{array}{l}\text { The teacher should command such learner to be on his/her feet for a few minutes, or punish } \\
\text { him/her to serve as a deterrent to others. }\end{array}$ \\
\hline 8 & $\begin{array}{l}\text { Writing/ } \\
\text { copying note }\end{array}$ & $\begin{array}{l}\text { The teacher should collect the notebook or textbook from such learner, punish him/her to } \\
\text { serve as a deterrent to others. }\end{array}$ \\
\hline 9 & Playing & The teacher should separate the learners, punish them to serve as a deterrent to others. \\
\hline 10 & Laughing & $\begin{array}{l}\text { The teacher should tell the pupils/students that know the answer to the question to raise } \\
\text { their hands; call each pupil/student by name one after the other. }\end{array}$ \\
\hline 11 & Foot dragging & $\begin{array}{l}\text { The teacher should identify such learner(s) and punish them appropriately in the presence } \\
\text { of other learners. } \\
\text { The teacher should also make his/her teaching to be interactive and interesting to the } \\
\text { learners. }\end{array}$ \\
\hline 12 & Noisemaking & $\begin{array}{l}\text { The teacher should identify those learners involved and give them appropriate punishment. } \\
\text { He/she should also avoid the practice of chorus answering of questing by the learners which } \\
\text { can encourage this. }\end{array}$ \\
\hline 13 & Farting & $\begin{array}{l}\text { The teacher should first identify the learner concerned and let him/her stay outside the class } \\
\text { for a few minutes so that the odor can ooze out completely after which he/she can be re- } \\
\text { admitted into the classroom. }\end{array}$ \\
\hline 14 & Hissing & The teacher should identify the learner involved and give him/her appropriate punishment. \\
\hline 15 & $\begin{array}{l}\text { Ringing of/ } \\
\text { discussion on } \\
\text { Phone: }\end{array}$ & $\begin{array}{l}\text { The teacher should identify the particular learner, seize such a phone from him/her, give } \\
\text { him/her appropriate punishment. }\end{array}$ \\
\hline 16 & Yawning & $\begin{array}{l}\text { The teacher should identify the learner involved, give him/her appropriate punishment, } \\
\text { make his/her teaching to be more interactive. }\end{array}$ \\
\hline 17 & Pen twirling & $\begin{array}{l}\text { The teacher should identify the learner involved and assign appropriate punishment to } \\
\text { him/her. }\end{array}$ \\
\hline 18 & $\begin{array}{l}\text { Learners not } \\
\text { relating with } \\
\text { others }\end{array}$ & $\begin{array}{l}\text { The teacher should give role(s) to such learners, direct questions to him/them, or involve } \\
\text { him/her in group activities in the class. }\end{array}$ \\
\hline
\end{tabular}

Note: Appropriate punishment, as used in the context of this table varies but depends on the decision of the teacher. Such punishment must however bot be the type that will disenable a learner from missing the lesson completely because of the consequences.

As indicated in Table 1, there are different behavioural challenges in the classroom, such as sleeping, eating, fighting, yawning, noisemaking, among others, by students. Each challenge however has its way of managing it, as indicated after ut in the same table. 


\section{Conclusion}

A classroom serves as a place where information is disseminated to the learners. In other words, it is a place where a teacher teaches the learners. Effective management of the classroom is imperative for effective teaching to be achieved by a teacher. Effective teaching however requires considerable skill in managing the situations in the classroom. Effective classroom management skill is central to teaching and requires common sense, consistency, a sense of fairness, and courage, which can be acquired through practice, feedback, and willingness to learn from mistakes.

\section{References}

Aanuoluwapo, B. O., \& Akinyemi, T. F. (2016). Teaching and teacher education: A case study of National Teachers' Institute Postgraduate Diploma in education programme. Journal of Open Learning and Teacher Education, 3(2), 26-45.

Borism, K., \& Jens, G. (2019). HR governance: A theoretical introduction. USA: Springer Publishing Company.

Carmen, W. (2019). Role of the classroom teacher. Retrieved from: https://www.teachingvisuallyimpaired.com/role-of-the-classroomteacher.html.

Evertson, C. M., \& Weinstein, C. S. (2006). Classroom management as a field of inquiry. In C. M. Evertson \& C.S.Weinstein(Eds.), Handbook of classroom management: Research, practice, and contemporary issues (pp. 3-16). Mahwah, NJ: Lawrence Erlbaum Associates.

Marland, M. (1975). The craft of the classroom: A survival guide to classroom management in the secondary school. London: Heinemann Educational Publisher.

National Teachers Institute. (2013). Effective classroom management skills. Manual for retraining of primary school teachers. A Millenium Development Goals(MDGs) Project. Abuja, Nigeria: National Teachers Institute.

Nwachukwu, C. C. (1988). Management: Theory and practice. Ibadan, Nigeria: Africana FEP Publisher.

Nwagbo, C. (2008). Science, technology, and Mathematics (STM) Curriculum delivery. Paper presented at the The 49th Annual Conference of Science Teachers Association of Nigeria, held at Yenagoa, Nigeria.

Oliver, R. M., Wehby, J. H., \& Reschly, D. J. (2011). Teacher classroom management practices: Effects on disruptive or aggressive student behavior. Campbell Systematic Reviews, 7(1), 1-55. Available at: https://doi.org/10.4073/csr.2011.4

Out, D. O. (2002). The effects of the environment in public learning: A case study of schools in Nigeria Metropolis, Kaduna State. Universal Basic Education (UBE) Forum, 2(2), 11-20.

Rakum, S. A. (2007). Assessment of social studies curriculum in secondary schools in Gombe Metropolis. Unpublished Ph.D. Thesis, University of Maiduguri.

Rockoff, J. E. (2004). The impact of individual teachers on student achievement: Evidence from panel data. American Economic Review, 94(2), 247-252. Available at: https://doi.org/10.1257/0002828041302244.

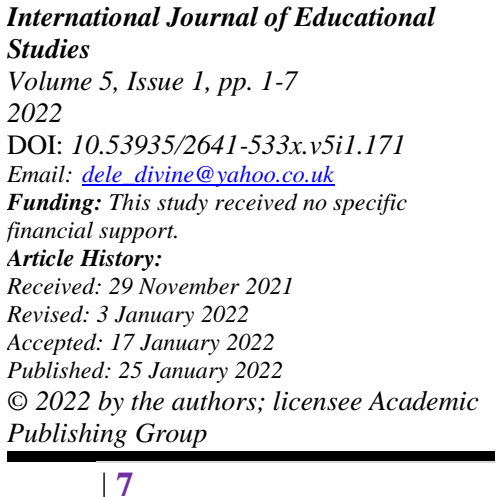

